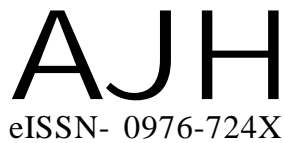

Received : 01.02.2016

Revised : 18.04 .2016

Accepted : 28.04.2016

Members of the Research Forum

Associated Authors:

${ }^{1}$ Department of Horticulture,

Jawaharlal Nehru Krishi Vishwa

Vidyalaya, JABALPUR (M.P.) INDIA

Author for correspondence :

N.R. RANGARE

Department of Horticulture,

Jawaharlal Nehru Krishi Vishwa

Vidyalaya, JABALPUR (M.P.) INDIA

Email : nrrangare@gmail.com
THEASIAN JOURNALOF HORTICULTURE

Volume 11 | Issue 1 | June, 2016 | 93-95

Visit us -www.researchjournal.co.in

RESEARCH PAPER

DOI : 10.15740/HAS/TAJH/11.1/93-95

\title{
Bio-efficacy of azoxystrobin fungicide against anthracnose disease of mango (Mangifera indica L.)
}

\section{S.K. PANDEY ${ }^{1}$, U.K. CHANDERIA ${ }^{1}$ AND N.R. RANGARE}

ABSTRACT : The present field investigation on "bio-efficacy of azoxystrobin 23 per cent SC against anthracnose in mango was conducted at Fruit Research Farm, Imaliya, Department of Horticulture, JNKVV, Jabalpur (Madhya Pradesh) during Kharif season 2014, to estimated the bio-efficiency of used fungicide against Anthracnose (Colletotrichum gloeosporioides) by different doses and time interval of application. The present field experiment resulted that all the treatments showed significant effect in increasing the yield of mango, among all the treatments azoxystrobin 23 per cent SC @ 188g a.i./ha produced maximum yield (121.66 kg/plot). While, minimum yield was estimated in treatment comparison (Mancozeb 75\% WP) a.i./ha (70kg/plot) after each spray of chemical followed by market sample azoxystrobin 23 per cent SC @ 125 a.i./ ha (76 kg/plot) and azoxystrobin 23 per cent SC @376 a.i./ha (72kg/plot).

KEY WORDS : Mango, Anthracnose (Colletotrichum gloeosporioides), Azoxystrobin

HOW TO CITE THIS ARTICLE : Pandey, S.K., Chanderia, U.K. and Rangare, N.R. (2016). Bio-efficacy of azoxystrobin fungicide against anthracnose disease of mango (Mangifera indica L.). Asian J. Hort., 11(1) : 93-95, DOI : 10.15740/HAS/TAJH/11.1/93-95. 